\title{
PENGARUH KESESUAIAN TUGAS-TEKNOLOGI, KEPERCAYAAN DAN EFEKTIVITAS SISTEM INFORMASI AKUNTANSI TERHADAP KINERJA INDIVIDU PADA PASARSWALAYAN DI KOTA TANGERANG
}

\author{
Agnes Ashianti \\ Universitas Multimedia Nusantara \\ agnes.ashianti21@yahoo.com
}

\begin{abstract}
The objective of this research is to examine the effect of task-technology fit, trust of accounting information systems, and effectiveness of accounting information systems on the individual performance at a supermarket in Tangerang city.

The samples in this study were employees of a supermarket in Tangerang city who used accounting information system in doing its job. The data used in this study is primary data through questionnaires. In data analysis techniques, this study test the reliability of the formula coefficient of Cronbach 's Alpha, validity test by means of correlation using the $r$ counted and $r$ table, test for normality using Kolmogorov-Smirnov test, the classical assumption, hypothesis testing multiple linear regression, $t$ test, and $F$ test.

The results showed that the task-technology fit and trust of accounting information systems each have a significant effect on the individual performance, while the effectiveness of accounting information systems does not significantly influence the individual performance. Task-technology fit, trust of accounting information systems, and the effectiveness of accounting information systems have simultaneous significant effect on the individual performance.
\end{abstract}

Keyword: Task-Technology Fit, Trust of Accounting Information Systems, Effectiveness of Accounting Information Systems, Individual Performance.

\section{PENDAHULUAN}

Penggunaan teknologi sistem informasi membuat setiap organisasi sekarang menganggap bahwa sistem informasi sangat penting bagi kelangsungan hidup perusahaan. Hal tersebut mempengaruhi hampir semua aspek dalam pengelolaan bisnis, termasuk dalam pengelolaan bisnis pasar swalayan. Pasar swalayan merupakan bisnis yang bergerak dalam bidang perdagangan eceran sebagaimana halnya toko kelontong yang tersebar dimana-mana. Kelengkapan barang yang dijual, sistem pengelolaan, dan sarana yang disediakan membuatnya berbeda dengan toko kelontong dan pasar tradisional. Oleh karena itu, agar dapat membuat keputusan secara cepat dan akurat, maka sistem informasi yang menampung seluruh informasi dari pasar swalayan sangat dibutuhkan. Misalnya, vendor dapat memeriksa catatan persediaan pasar swalayan melalui internet untuk mengisi kembali persediaannya saat 
mencapai tingkat persediaan minimum (Vaassen et al., 2009).

Keberhasilan penerapan suatu sistem informasi bergantung pada kemudahan dan pemanfaatan sistem tersebut oleh pemakai sistem karena teknologi sistem informasi diselengarakan dalam suatu perusahaan untuk membantu individu dalam menyelesaikan tugasnya (Goodhue dan Thompson, 1995). Oleh sebab itu, penerapan teknologi dalam sistem informasi perusahaan atau organisasi hendaknya mempertimbangkan pemakai sistem sehingga teknologi yang diterapkan sesuai dengan tugas dan kemampuan pemakai. Tidak jarang teknologi yang diterapkan dalam sistem informasi kurang memberikan manfaat dalam meningkatkan kinerja individu karena tidak sesuai dengan kebutuhan pengguna (Jumaili, 2005).

Selain itu, kepercayaan terhadap sistem informasi merupakan hal yang diperlukan bagi pemakai agar merasa sistem informasi tersebut bermanfaat dan dapat meningkatkan kinerja dalam menjalankan kegiatannya. Kepercayaan ini bisa muncul karena kecepatan proses teknologi sistem informasi dalam membantu pekerjaan dan rasa keadilan bahwa penerapan teknologi informasi ini dapat menilai kinerja dengan lebih baik. Organisasi yang memiliki kepercayaan terhadap sistem informasi akan berusaha untuk menggunakan teknologi sistem informasi untuk mendukung kinerjanya.

Kinerja individu dalam suatu organisasi atau perusahaan menjadi faktor yang penting untuk menilai kinerja perusahaan, yang menjadi penilaian terhadap perusahaan itu sendiri di mata investor, perusahaan lain, maupun masyarakat luas. Kehadiran sistem informasi akuntansi yang membantu perusahaan dalam menjalankan operasinya agar lebih efektif dan efisien juga merubah tata cara kinerja individu secara manual yang sudah mulai ditinggalkan. Namun, penerapan sistem informasi akuntansi dalam perusahaan khususnya pasar swalayan, tidak dimanfaatkan secara maksimal oleh individu pemakai sistem informasi. Hal ini menyebabkan kurangnya manfaat yang diberikan oleh sistem informasi tersebut khususnya dalam meningkatkan kinerja individu (Sari, 2009).

Perusahaan memiliki alternatif dalam memilih paket program sistem informasi akuntansi antara yang dijual dalam paket yang sudah jadi atau dapat memesan khusus sesuai dengan karakteristik dan kebutuhan perusahaan (Hall, 2011: 173). Kemampuan masing-masing paket program sistem informasi akuntansi ini sangat bervariasi mulai dari yang sederhana dengan aplikasi tertentu hingga 
yang memiliki kemampuan tinggi dan terintegrasi dengan sistem Enterprise Resource Planning (ERP). Investasi yang terkait dengan teknologi informasi seperti pembelian paket program sistem informasi akuntansi ini memakan biaya yang tidak sedikit sehingga perlu dipertimbangkan oleh perusahaan apakah investasi ini memberikan lebih banyak manfaat dibandingkan biaya yang dikeluarkannya. Rumusan Masalah

1. Apakah kesesuaian tugas-teknologi berpengaruh positif terhadap kinerja individu?

2. Apakah kepercayaan sistem informasi akuntansi berpengaruh positif terhadap kinerja individu?

3. Apakah efektivitas sistem informasi akuntansi berpengaruh positif terhadap kinerja individu?

4. Apakah kesesuaian tugasteknologi, kepercayaan dan efektivitas sistem informasi akuntansi secara simultan berpengaruh positif terhadap kinerja individu?

\section{TELAAH LITERATUR}

\subsection{Sistem Informasi Akuntansi}

Sajady et al. (2008) menyatakan bahwa sistem informasi akuntansi sebagai bagian dari sistem informasi manajemen (management information system).
Romney dan Steinbart (2012) menjelaskan bahwa sistem informasi akuntansi mengumpulkan, mencatat, menyimpan, dan memproses data akuntansi dan data lainnya untuk menghasilkan informasi bagi pembuat keputusan. Vaassen et al. (2009) menyatakan bahwa sistem informasi akuntansi mempelajari penataan dan proses perencanaan dan pengendalian operasi yang ditujukan untuk:

1. Menyediakan informasi untuk membuat keputusan dan akuntabilitas kepada pihak internal dan eksternal berkepentingan yang sesuai dengan kriteria kualitas yang diterapkan.

2. Menyediakan kondisi yang tepat untuk pengambilan keputusan.

3. Memastikan bahwa tidak ada aset yang keluar organisasi secara tidak sah.

Sistem informasi akuntansi menyediakan data utama untuk pengambilan keputusan. Teknologi informasi telah menyebabkan banyak perubahan dalam pelaporan informasi. Dengan demikian, karakteristik informasi yang saat ini dibuat dapat membantu pembuat keputusan mencari lebih banyak alternatif untuk solusi pada masalah yang dihadapi (Sajady et al., 2008). 


\subsection{Kesesuaian Tugas-Teknologi}

Tugas secara luas didefinisikan sebagai kegiatan yang dilakukan oleh individu dalam mengubah input menjadi output. Sedangkan teknologi dipandang sebagai alat yang digunakan oleh individu dalam mengerjakan tugasnya. Individu akan menggunakan teknologi untuk membantu mereka dalam meningkatkan kinerja (Goodhue dan Thompson, 1995).

Dalam bekerja dengan teknologi informasi, individu mencari solusi yang lebih sederhana, user friendly, andal dan stabil yang akan berguna untuk pekerjaan mereka (Tennakoon dan Syed, 2011). Goodhue (1995) dalam Hamzah (2009) membuat model Task-Technology Fit (TTF) yang merupakan korespondensi antara kebutuhan tugas, kemampuan individual, dan fungsi-fungsi teknologi dalam sistem informasi akuntansi perusahaan. Kebutuhan tugas harus sesuai dengan kemampuan individu yang didukung dengan fungsi-fungsi teknologi sistem informasi. Ketiga hal tersebut merupakan satu kesatuan, apabila salah satu tiada maka akan berakibat pada ketidakoptimalan kinerja individu maupun sistem informasi tersebut.

\subsection{Kepercayaan Sistem Informasi} Akuntansi
Kepercayaan digambarkan sebagai suatu tindakan kognitif (bentuk pendapat atau prediksi bahwa sesuatu akan terjadi atau orang akan berperilaku dalam cara tertentu), afektif (masalah perasaan) berupa masalah pilihan atau keinginan (Hamzah, 2009). Menurut Davis (1989) dalam Seddon dan Kiew (2007), kegunaan sistem informasi adalah sejauh mana seseorang percaya bahwa menggunakan sistem tertentu akan meningkatkan kinerjanya. Keyakinan akan penggunaan tersebut berhubungan dengan manfaat masa depan dalam melakukan beberapa tugas. Berdasarkan definisi di atas dapat disimpulkan bahwa kepercayaan sistem informasi akuntansi menggambarkan sikap pemakai tentang keyakinan bahwa sistem informasi akuntansi yang digunakan dapat meningkatkan kinerja dengan manfaat di masa depan.

Bentuk pendapat atau prediksi akan mempengaruhi kepercayaan pada orang lain yang akan mempengaruhi perilaku individu dan berdampak pada kinerja organisasi. Begitu pula masalah pilihan atau keinginan juga berpengaruh pada tingkat kepercayaan individu terhadap sistem informasi akuntansi yang digunakan. Individu yang diberikan pilihan tetapi bukan keinginannya akan menurunkan kepercayaan terhadap penggunaan sistem informasi akuntansi 
tersebut. Individu yang menginginkan sistem informasi akuntansi yang dipercaya tetapi tidak mempunyai pilihan sesuai keinginannya juga akan menurunkan kepercayaan terhadap sistem informasi akuntansi tersebut. Kepercayaan individu akan tumbuh pada sistem informasi akuntansi, apabila keinginan individu tersebut terpenuhi sesuai dengan pilihannya (Hamzah, 2009).

\subsection{Efektivitas Sistem Informasi Akuntansi} Menurut O’Brien dan Marakas (2008), kesuksesan sebuah sistem informasi harus diukur berdasarkan keefektifan teknologi informasi dalam mendukung strategi bisnis organisasi, memungkinkan proses bisnisnya, mempertinggi struktur dan budaya organisasi, dan meningkatkan nilai pelanggan dan bisnis perusahaan. Dehghanzade et al. (2011) mendefinisikan efektivitas sistem informasi akuntansi sebagai persepsi pembuat keputusan bahwa output informasi yang tersedia kepada mereka melalui pemrosesan transaksi, pelaporan manajemen, dan sistem anggaran memenuhi kebutuhan mereka untuk koordinasi dan pengendalian organisasi.

Choe (1998) dalam Sajady et al. (2008) menyatakan bahwa efektivitas sistem informasi akuntansi dapat dianalisis pada tiga basis:
1. Lingkup informasi, yaitu informasi keuangan dan non-keuangan, informasi internal dan eksternal yang berguna dalam memprediksi kejadian masa depan.

2. Tepat waktu, yang berhubungan dengan kemampuan sistem informasi akuntansi untuk memenuhi kebutuhan informasi dengan memberikan laporan yang sistematis ke pengguna.

3. Agregasi informasi, yang dianggap sebagai sarana mengumpulkan dan meringkas informasi dalam jangka waktu tertentu.

Jumaili (2005) mengemukakan bahwa secara umum, efektivitas penggunaan atau pengimplementasian teknologi sistem informasi dalam suatu perusahaan dapat dilihat dari kemudahan pemakai dalam mengidentifikasi data, mengakses data dan menginterpretasikan data tersebut. Diharapkan dengan penggunaan sistem informasi akuntansi, individu dari perusahaan atau organisasi yang merupakan pemakai sistem tersebut dapat menghasilkan output yang semakin baik dan kinerja yang dihasilkan tentu akan meningkat.

\subsection{Kinerja Individu}

Istilah kinerja berasal dari kata job performance atau actual performance 
(prestasi kerja atau prestasi yang sesungguhnya dicapai oleh seseorang). As'ad (1991) dalam Sari (2009) beranggapan bahwa kinerja adalah hasil yang dicapai seseorang menurut aturan yang berlaku untuk pekerjaan yang bersangkutan. Menurut Cecilia (2006) dalam Salamah (2012), kinerja individu mengacu pada prestasi kerja individu yang diatur berdasarkan stardar atau kriteria yang telah ditetapkan oleh suatu organisasi.

Penilaian kinerja merupakan faktor utama dalam mengembangkan suatu organisasi secara efektif dan efisien, karena adanya kebijakan atau program yang lebih baik atas sumber daya manusia yang ada dalam organisasi. Penilaian kinerja individu sangat bermanfaat bagi dinamika pertumbuhan organisasi secara keseluruhan. Penilaian kinerja dapat menunjukkan bagaimana kinerja individu secara nyata.

\subsection{Pengaruh Kesesuaian Tugas-Teknologi} terhadap Kinerja Individu

Goodhue dan Thompson

mengemukakan bahwa agar suatu sistem informasi dan teknologi informasi dapat memberikan dampak yang positif terhadap kinerja individu maka teknologi tersebut harus dimanfaatkan dengan tepat dan harus mempunyai kecocokan dengan tugas yang didukungnya. Kebutuhan tugas, kemampuan individu, dan fungsi-fungsi teknologi sistem informasi merupakan satu kesatuan yang tidak boleh dipisahkan agar kinerja individu dapat optimal (Hamzah, 2009; Lindawati dan Salamah, 2012). Kesesuaian tugas-teknologi memicu pemanfaatan sistem informasi akuntansi untuk menyelesaikan tugas yang akhirnya akan meningkatkan kinerja individu.

Ha1: Kesesuaian tugas-teknologi berpengaruh positif terhadap kinerja individu.

\subsection{Pengaruh Kepercayaan Sistem} Informasi Akuntansi terhadap Kinerja Individu

Kepercayaan adalah hal yang diperlukan individu pemakai sistem informasi akuntansi agar ia merasa bahwa sistem informasi akuntansi dapat meningkatkan kinerja individu dalam menjalankan kegiatan organisasi/ perusahaan. Bentuk pendapat atau prediksi akan mempengaruhi kepercayaan pada sistem informasi tersebut yang akan mempengaruhi perilakunya dan berdampak pada kinerja organisasi. Kepercayaan dipertimbangkan sebagai sesuatu yang utama dapat disampaikan dengan aturan yang spesifik untuk komunikasi meliputi standar, operasi dan prosedur tertentu sehingga orang lain dapat 
menggunakan sistem informasi akuntansi tersebut tanpa adanya halangan yang berarti (Hamzah, 2009). Sistem informasi yang dipercaya oleh individu dapat meningkatkan kinerjanya akan menghasilkan tingkat pencapaian kinerja yang lebih baik oleh individu. Sistem yang berkualitas tinggi akan mempengaruhi kepercayaan pemakai bahwa dengan sistem tersebut tugas-tugas yang dihadapi akan lebih mudah dan cepat diselesaikan (Jumaili, 2005).

Ha2: Kepercayaan sistem informasi akuntansi berpengaruh positif terhadap kinerja individu.

\subsection{Pengaruh Efektivitas Sistem Informasi} Akuntansi terhadap Kinerja Individu

Efektivitas sistem informasi akuntansi merupakan suatu ukuran yang memberikan gambaran sejauh mana target dapat dicapai dari suatu kumpulan sumber daya yang diatur untuk mengumpulkan, memproses dan menyimpan data elektronik, kemudian mengubahnya menjadi sebuah informasi yang berguna serta menyediakan laporan formal yang dibutuhkan dengan baik secara kualitas maupun waktu. Efektivitas sistem informasi akuntansi dinilai berdasarkan kualitas output dari sistem informasi yang dapat memuaskan kebutuhan pengguna (Sajady et al., 2008). Sistem informasi yang digunakan dengan baik akan meningkatkan proses kinerja karyawan sehingga menghasilkan informasi yang berkualitas.

Ha3: Efektivitas sistem informasi akuntansi berpengaruh positif terhadap kinerja individu.

2.9 Pengaruh Kesesuaian TugasTeknologi, Kepercayaan dan Efektivitas Sistem Informasi Akuntansi terhadap Kinerja Individu

Goodhue (1995) dalam Jumaili (2005) mengajukan konstruk hubungan kecocokan tugas teknologi untuk dijadikan sebagai acuan evaluasi pemakai dalam sistem informasi. Dalam model ini dinyatakan bahwa pemakai akan memberikan nilai evaluasi yang tinggi (positif) tidak hanya dikarenakan oleh karakteristik sistem yang melekat, tetapi lebih kepada sejauh mana sistem tersebut dipercaya dapat memenuhi kebutuhan tugas mereka dan sesuai dengan kebutuhan tugas mereka.

Sistem informasi akuntansi yang digunakan dipercaya dapat membantu individu dan organisasi dalam mengoptimalkan kinerja serta perilaku yang mendorong pada peningkatan kinerja. Sistem informasi akuntansi akan dapat mempermudah dan mempercepat proses penyelesaikan pekerjaan maupun untuk pengambilan keputusan yang diharapkan 
oleh pemakai informasi. Namun, akuntansi yang dimanfaatkan dengan baik perbedaan antara keinginan dengan pilihan akan memberikan pengaruh pada kinerja sistem informasi akuntansi yang tersedia individu melalui peningkatan proses berpengaruh pada tingkat kepercayaan individu terhadap sistem informasi akuntansi yang digunakan (Hamzah, 2009).

Kinerja yang lebih tinggi mengandung arti terjadinya peningkatan efisiensi, efektivitas atau kualitas yang lebih tinggi dari penyelesaian serangkaian tugas yang dibebankan kepada individu dalam perusahaan atau organisasi (Lindawati dan pengambilan keputusan, pengendalian internal, dan kualitas laporan keuangan dan memfasilitasi proses transaksi perusahaan sehingga dinilai efektif (Sajady et al., 2008).

Ha4: Kesesuaian tugas-teknologi, kepercayaan dan efektivitas sistem informasi akuntansi secara simultan berpengaruh positif terhadap kinerja individu.

Salamah, 2012). Sistem informasi

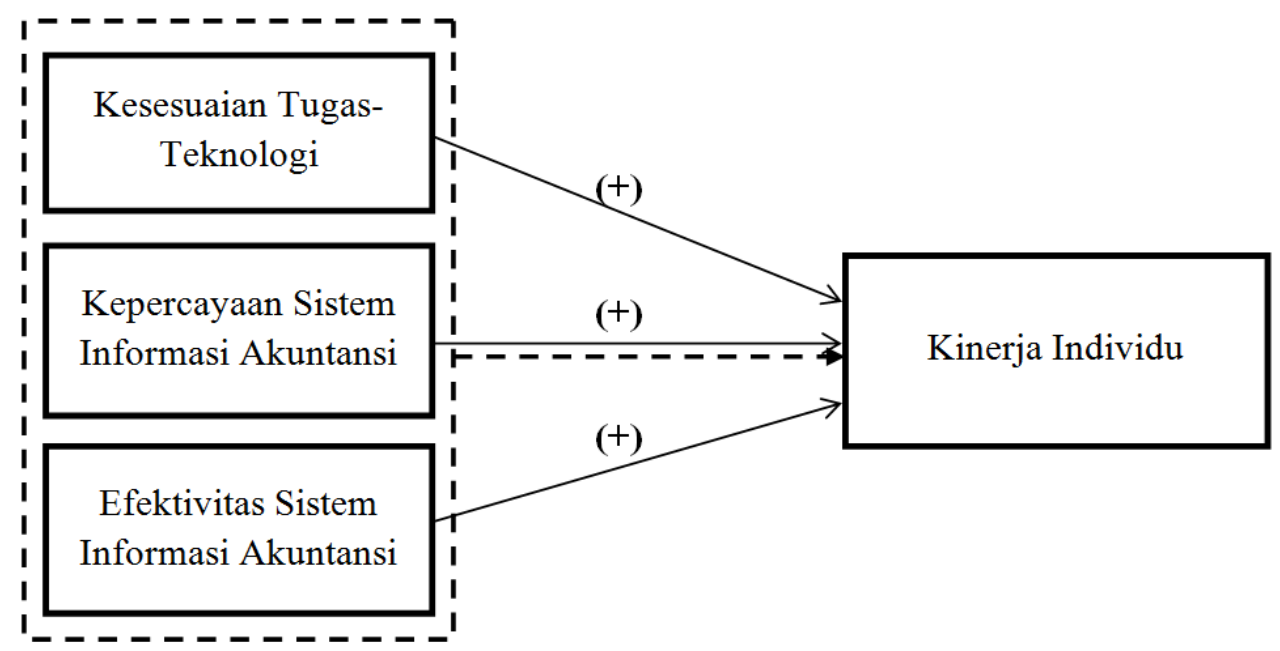

Gambar 1. Model Pemikiran

\section{METODOLOGI PENELITIAN}

Jenis penelitian ini adalah pengujian hipotesis berupa studi kausal yang menjelaskan hubungan sebab-akibat atau pengaruh dari kesesuaian tugas-teknologi, kepercayaan, dan efektivitas sistem informasi akuntansi terhadap kinerja individu pada pasar swalayan di kota Tangerang. Jenis data dalam penelitian ini adalah data primer di mana data yang diperoleh dari sumber pertama baik dari 
individu atau perorangan menggunakan kuesioner.

Teknik penentuan sampel yang digunakan dalam penelitian ini adalah dengan menggunakan teknik non probability sampling. Non probability sampling adalah teknik pengambilan sampel yang tidak memberikan peluang/ kesempatan yang sama bagi setiap unsur atau anggota populasi untuk dipilih menjadi sampel (Sugiyono, 2010). Teknik pengambilan sampel yang digunakan dalam penelitian ini adalah convenience sampling, yaitu metode penentuan sampel berdasarkan kemudahan dalam pengambilan data. Sampel yang digunakan dalam penelitian ini adalah karyawan pasar swalayan yang menggunakan sistem informasi akuntansi dalam mengerjakan tugasnya.

Definisi Operasional Variabel

Variabel Independen

Kesesuaian Tugas-Teknologi

Kesesuaian tugas-teknologi adalah interaksi antara karakteristik-karakteristik seperti individual pemakai, teknologi yang digunakan, dan tugas yang berbasis teknologi (korespondensi antara kebutuhan tugas, kemampuan individual dan fungsi teknologi (Akbar et al., 2010). Kesesuaian tugas-teknologi diukur dengan instrumen yang diadopsi dari Goodhue (1995) dan Jumaili (2005) yang terdiri atas 7 butir pernyataan untuk 5 dimensi construct, antara lain:

- Lokabilitas, yang terdapat pada pernyataan nomor 1 dan 2 .

- Otoritas, yang terdapat pada pernyataan nomor 3 .

- Ketepatan waktu dalam menyelesaikan tugas, yang terdapat pada pernyataan nomor 4 .

- Keandalan sistem, yang terdapat pada pernyataan nomor 5 .

- Kemudahan dan pelatihan penggunaan sistem, yang terdapat pada pernyataan nomor 6 dan 7 .

Instrumen ini diukur menggunakan skala interval dengan 5 skala Likert dengan pemberian skor 1 sampai 5 .

Kepercayaan Sistem Informasi Akuntansi Kepercayaan sistem informasi akuntansi adalah keyakinan bahwa sistem informasi akuntansi yang digunakan dapat membantu mengoptimalkan kinerja agar bermanfaat di masa depan (Seddon dan Kiew, 2007). Kepercayaan sistem informasi akuntansi diukur dengan instrumen yang diadopsi dari Jumaili (2005), yang terdiri atas 4 butir pernyataan yang berkaitan dengan:

- Kecepatan penyelesaian pekerjaan.

- Penggunaan sistem informasi terbaru. 
- Dana yang dikeluarkan untuk sistem baru.

- Penilaian adil sistem informasi baru.

Instrumen ini diukur menggunakan skala interval dengan 5 skala Likert dengan pemberian skor 1 sampai 5 .

Efektivitas Sistem Informasi Akuntansi

Efektivitas sistem informasi akuntansi adalah persepsi pembuat keputusan bahwa output informasi yang tersedia kepada mereka melalui pemrosesan transaksi, pelaporan manajemen, dan sistem anggaran memenuhi kebutuhan mereka untuk koordinasi dan pengendalian organisasi (Dehghanzade et al., 2011). Efektivitas sistem informasi akuntansi diukur dengan menggunakan instrumen yang diadopsi dari Seddon dan Kiew (2007), yang terdiri atas 8 butir pertanyaan untuk dimensi construct kualitas informasi, antara lain:

- Apakah output disajikan dalam format yang berguna.

- Apakah informasinya jelas.

- Apakah sistemnya akurat.

- Apakah sistem memberikan informasi yang cukup.

- Apakah sistem memberikan informasi yang up-to-date.

- Apakah informasi didapatkan tepat waktu.
- Apakah sistem memberikan informasi sesuai yang dibutuhkan.

- Apakah isi informasi memenuhi kebutuhan.

Instrumen ini diukur menggunakan skala interval dengan 5 skala Likert dengan pemberian skor 1 sampai 5 .

Variabel Dependen - Kinerja Individu Kinerja individu mengacu pada prestasi kerja individu yang diatur berdasarkan standar atau kriteria yang telah ditetapkan oleh suatu organisasi (Cecilia, 2006 dalam Salamah, 2012). Kinerja individu diukur dengan instrumen yang diadopsi dari Jumaili (2005), yang terdiri atas 3 butir pertanyaan yang berkaitan dengan:

- Efektivitas dan produktivitas penyelesaian tugas, terdapat pada pernyataan nomor 1 dan 2 .

- Pengaruh yang dirasakan, terdapat pada pernyataan nomor 3 .

Instrumen ini diukur menggunakan skala interval dengan 5 skala Likert dengan pemberian skor 1 sampai 5 .

\section{Uji Kualitas Data}

Kualitas data yang dihasilkan dari penggunaan instrumen penelitian dapat dievaluasi melalui uji reliabilitas dan validitas. Uji tersebut masing-masing untuk mengetahui konsistensi dan keakuratan data yang dikumpulkan pada kuesioner. Uji reliabilitas diukur dengan 
uji statistik Cronbach Alpha ( $\alpha$ ). Suatu konstruk atau variabel dikatakan reliabel jika memberikan nilai Cronbach Alpha > 0,70 (Nunnally, 1994 dalam Ghozali, 2012: 48). Pengujian validitas dilakukan dengan membandingkan nilai $r$ hitung dengan $r$ table of degree of freedom $(\mathrm{df})=$ $\mathrm{n}-2$, dalam hal ini $\mathrm{n}$ adalah jumlah sampel. Apabila $\mathrm{r}$ hitung lebih besar daripada $r$ tabel, maka data dinyatakan valid (Ghozali, 2012: 52-53).

Uji normalitas bertujuan untuk menguji apakah dalam model regresi, variabel pengganggu atau residual memiliki distribusi normal (Ghozali, 2012). Metode

$$
\mathrm{Y}=\mathrm{a}+\mathrm{b}_{1} \mathrm{X}_{1}+\mathrm{b}_{2} \mathrm{X}_{2}+\mathrm{b}_{3} \mathrm{X}_{3}+\mathrm{e}
$$

Keterangan:

$\begin{array}{lll}\mathrm{Y} & : & \text { Kinerja individu } \\ \mathrm{a} & : & \text { Konstanta } \\ \mathrm{b}_{1} & : & \text { Koefisien regresi untuk X1 } \\ \mathrm{b}_{2} & : & \text { Koefisien regresi untuk X2 } \\ \mathrm{b}_{3} & : & \text { Koefisien regresi untuk X3 } \\ \mathrm{X}_{1} & : & \text { Kesesuaian tugas-teknologi } \\ \mathrm{X}_{2} & : & \text { Kepercayaan sistem informasi akuntansi } \\ \mathrm{X}_{3} & : & \text { Efektivitas sistem informasi akuntansi } \\ \mathrm{e} & : & \text { Error }\end{array}$

\section{HASIL DAN ANALISIS}

\section{Statistik Deskriptif Responden}

Kuesioner dibagikan kepada responden dengan cara mendatangi kantor pada masing-masing pasar swalayan melalui pintu masuk karyawan, atau dengan yang digunakan untuk uji normalitas yaitu uji statistik non-parametrik KolmogorovSmirnov (K-S). Jika nilai probabilitas signifikansi dari hasil pengujian lebih besar dari 0,05, maka data terdistribusi dengan normal (Ghozali, 2012). Apabila lebih kecil, maka data tidak terdistribusi dengan normal.

\section{Uji Hipotesis}

Analisis regresi linear berganda dipergunakan untuk memecahkan masalah dalam penelitian dengan model regresi linear berganda sebagai berikut: 
menolak. Jumlah kuesioner yang diberikan ke responden sebanyak 109 buah. Dari jumlah kuesioner yang diberikan tersebut, sebanyak 104 buah kuesioner yang dikembalikan. Berdasarkan jumlah kuesioner yang dikembalikan, sebanyak 8 buah kuesioner tidak dapat dipakai karena terdapat kuesioner yang tidak diisi dengan lengkap atau tidak diisi sama sekali. Oleh karena itu, jumlah kuesioner yang dapat dipakai untuk diolah datanya sebanyak 96 buah kuesioner

Tabel 1. Karakteristik Responden

\begin{tabular}{|c|c|c|c|}
\hline \multicolumn{2}{|c|}{ Kategori Identifikasi } & Jumlah & Persentase \\
\hline \multirow{6}{*}{ Umur } & $\leq 20$ tahun & 5 & $5,26 \%$ \\
\hline & $21-30$ tahun & 55 & $57,89 \%$ \\
\hline & $31-40$ tahun & 26 & $27,37 \%$ \\
\hline & $41-50$ tahun & 9 & $9,47 \%$ \\
\hline & $\geq 51$ tahun & 0 & $0,00 \%$ \\
\hline & Total & 95 & $100,00 \%$ \\
\hline \multirow{4}{*}{ Jenis Kelamin } & Pria & 49 & $51,04 \%$ \\
\hline & Wanita & 47 & $48,96 \%$ \\
\hline & Total & 96 & $100,00 \%$ \\
\hline & SMA & 71 & $74,74 \%$ \\
\hline Pendidikan & Diploma & 13 & $13,68 \%$ \\
\hline \multirow[t]{7}{*}{ Terakhir } & $\mathrm{S} 1$ & 11 & $11,58 \%$ \\
\hline & Total & 95 & $100,00 \%$ \\
\hline & Staff & 48 & $50,00 \%$ \\
\hline & Senior Staff & 6 & $6,25 \%$ \\
\hline & Operator & 2 & $2,08 \%$ \\
\hline & Team Leader & 4 & $4,17 \%$ \\
\hline & Assistant Supervisor & 2 & $2,08 \%$ \\
\hline \multirow[t]{7}{*}{ Jabatan } & Supervisor & 7 & $7,29 \%$ \\
\hline & Section Head & 2 & $2,08 \%$ \\
\hline & Assistant Department Head & 3 & $3,13 \%$ \\
\hline & Department Head & 10 & $10,42 \%$ \\
\hline & Manager & 12 & $12,50 \%$ \\
\hline & Total & 96 & $100,00 \%$ \\
\hline & $\leq 1$ tahun & 1 & $1,04 \%$ \\
\hline Pengalaman & $1-5$ tahun & 65 & $67,71 \%$ \\
\hline Menggunakan & $5-10$ tahun & 21 & $21,88 \%$ \\
\hline \multirow[t]{2}{*}{ SIA } & $>10$ tahun & 9 & $9,38 \%$ \\
\hline & Total & 96 & $100,00 \%$ \\
\hline
\end{tabular}

Berdasarkan karakteristik responden dari Tabel 1, dapat dilihat bahwa sebagian besar responden berumur antara $21-30$ tahun, yaitu sebesar 57,89\%. Jenis kelamin responden pria sebesar 51,04\%, sedangkan responden wanita sebesar 48,96\%. Mayoritas pendidikan terakhir responden berada pada tingkat SMA, yaitu sebesar 
74,74\%. Sebagian besar responden menjabat sebagai Staff di pasar swalayan, yaitu sebesar 50,00\%. Sebagian besar responden memiliki pengalaman menggunakan sistem informasi akuntansi berkisar antara $1-5$ tahun, yaitu sebesar $67,71 \%$.

Tabel 2. Statistik Deskriptif

\begin{tabular}{|l|r|r|r|r|r|}
\hline \multicolumn{1}{|c|}{ Descriptive Statistics } \\
\hline Total Kesesuaian & 96 & Minimum & Maximum & Mean & Std. Deviation \\
Total Kepercayaan & 96 & 35 & 28,48 & 3,744 \\
Total Efektivitas & 96 & 5 & 20 & 16,57 & 2,307 \\
Total Kinerja & 96 & 3 & 40 & 31,06 & 4,502 \\
Valid N (listwise) & 96 & 15 & 12,36 & 1,876 \\
\hline
\end{tabular}

Berdasarkan tabel diatas, jawaban responden cenderung berada pada nilai skor 4 dan 5 sehingga memiliki nilai ratarata (mean) jawaban yang cukup tinggi. Rata-rata jawaban dari 96 responden adalah 28,48 untuk variabel kesesuaian tugas-teknologi; 16,57 untuk variabel kepercayaan sistem informasi akuntansi; 31,06 untuk variabel efektivitas sistem informasi akuntansi; dan 12,36 untuk variabel kinerja individu.

\section{Uji Reliabilitas}

Tabel 3. Hasil Uji Reliabilitas

\begin{tabular}{lr}
\hline \multicolumn{1}{c}{ Variable } & $\begin{array}{c}\text { Cronbach's Alpha Based } \\
\text { on Standardized Items }\end{array}$ \\
\hline Kesesuaian tugas-teknologi & 0,791 \\
Kepercayaan sistem informasi akuntansi & 0,719 \\
Efektivitas sistem informasi akuntansi & 0,874 \\
Kinerja individu & 0,812 \\
\hline
\end{tabular}

Berdasarkan hasil uji reliabilitas yang dilakukan, didapatkan hasil Cronbach's Alpha untuk variabel kesesuaian tugasteknologi adalah 0,791; kepercayaan sistem informasi akuntansi adalah 0,719; efektivitas sistem informasi akuntansi adalah 0,874; serta kinerja individu memiliki nilai Cronbach's Alpha sebesar 0,812. Keempat variabel yang diuji memiliki nilai Cronbach's Alpha di atas 0,70, maka data tersebut dapat dikatakan reliable. 


\section{Uji Validitas}

Uji validitas dilakukan dengan dilihat dari $r$ table (two tailed) dengan $\alpha=$ membandingkan nilai $r$ hitung dengan $r$ table of degree of freedom $(\mathrm{df})=\mathrm{n}-2$. Dalam hal ini $\mathrm{n}$ adalah jumlah sampel. 0,05 adalah 0,2006. Kemudian dapat Dalam penilitian ini menggunakan 96 dilihat tampilan Cronbach Alpha pada kolom Corrected Item - Total Correlation untuk melihat hasil uji data tersebut valid sampel, sehingga df $=96-2=94$. Dapat atau tidak.

Tabel 4. Hasil Uji Validitas

\begin{tabular}{|l|r|}
\hline \multicolumn{2}{|c|}{ Item-Total Statistics } \\
\hline & $\begin{array}{c}\text { Corrected } \\
\text { Totem- } \\
\text { kesesuaian1 }\end{array}$ \\
kesesuaian2 &, 565 \\
kesesuaian3 &, 644 \\
kesesuaian4 &, 298 \\
kesesuaian5 &, 514 \\
kesesuaian6 &, 575 \\
kesesuaian7 &, 507 \\
kepercayaan1 &, 548 \\
kepercayaan2 &, 511 \\
kepercayaan3 &, 496 \\
kepercayaan4 &, 597 \\
efektivitas1 &, 433 \\
efektivitas2 &, 596 \\
efektivitas3 &, 708 \\
efektivitas4 &, 607 \\
efektivitas5 &, 645 \\
efektivitas6 &, 444 \\
efektivitas7 &, 683 \\
efektivitas8 &, 610 \\
kinerja1 &, 665 \\
kinerja2 & \\
kinerja3 &, 502 \\
\hline
\end{tabular}

Dapat dilihat dari Tabel 4 Corrected Item Total Correlation untuk seluruh variabel yang merupakan $r$ hitung seluruh nilainya berada di atas $r$ tabel 0,2006, sehingga dapat disimpulkan semua indikator dinyatakan valid. 


\section{Uji Normalitas}

Tabel 5. Hasil Uji Normalitas

\begin{tabular}{|ll|r|}
\hline \multicolumn{2}{|c|}{ One-Sample Kolmogorov-Smirnov Test } \\
\hline $\mathrm{N}$ & $\begin{array}{c}\text { Unstandardized } \\
\text { Residual }\end{array}$ \\
Normal Parameters ${ }^{\mathrm{a}, \mathrm{b}}$ & Mean & 96 \\
& Std. Deviation & $0 \mathrm{E}-7$ \\
& Absolute & 1,05212087 \\
Most Extreme Differences & Positive &, 067 \\
& Negative &, 067 \\
Kolmogorov-Smirnov Z & &,- 057 \\
Asymp. Sig. (2-tailed) & &, 657 \\
\end{tabular}

a. Test distribution is Normal.

b. Calculated from data.

Dapat dilihat dari Tabel 8 besarnya nilai Kolmogorov-Smirnov adalah 0,657 dan signifikan pada $0,782>0,05$ yang berarti data terdistribusi dengan normal.

\section{Uji Asumsi Klasik}

\section{Uji Multikolinearitas}

Menurut Ghozali (2012), uji multikolinearitas bertujuan untuk menguji apakah model regresi ditemukan adanya korelasi antar variabel independen. Untuk mendeteksi ada atau tidaknya multikolinearitas di dalam model regresi pada penelitian ini dapat dilihat dari nilai tolerance dan variance inflation factor (VIF). Tolerance mengukur variabilitas variabel independen yang terpilih yang tidak dijelaskan oleh variabel independen lainnya. Nilai cut off yang umum dipakai untuk menunjukkan adanya multikolinearitas adalah nilai Tolerance $\leq$ 0,10 atau sama dengan nilai $\mathrm{VIF} \geq 10$. Jadi, jika seluruh nilai Tolerance $>0,10$ dan VIF < 10 maka tidak terjadi multikolinearitas di antara variabel independennya (Ghozali, 2012: 106). 
Tabel 6. Hasil Uji Multikolinearitas

\begin{tabular}{|l|r|c|}
\hline \multirow{2}{*}{ Model } & \multicolumn{2}{|c|}{ Coefficients $^{\mathbf{a}}$} \\
\cline { 2 - 3 } & Tollinearity Statistics \\
\hline (Constant) & & \multicolumn{1}{|c|}{ VIF } \\
Total Kesesuaian &, 517 & 1,935 \\
1 Total Kepercayaan &, 635 & 1,574 \\
Total Efektivitas &, 561 & 1,782 \\
\hline
\end{tabular}

a. Dependent Variable: Total Kinerja

Hasil perhitungan nilai Tolerance menunjukkan tidak adanya variabel independen yang memiliki nilai Tolerance kurang dari 0,1 yang berarti tidak ada korelasi antar variabel independen yang nilainya lebih dari 95\%. Hasil perhitungan nilai Variance Inflation Factor (VIF) juga menunjukkan hal yang sama, yaitu tidak ada variabel independen yang memiliki nilai VIF lebih dari 10. Jadi, dapat disimpulkan bahwa tidak ada multikolinearitas antar variabel independen dalam model regresi.

\section{Uji Heteroskedastisitas}

Uji heteroskedastisitas bertujuan untuk menguji apakah model regresi terjadi ketidaksamaan variance dari residual satu pengamatan ke pengamatan lain. Deteksi ada tidaknya heteroskedastisitas dapat dilakukan dengan melihat ada tidaknya pola tertentu pada grafik Scatterplot antara nilai prediksi variabel dependen dengan residualnya. 


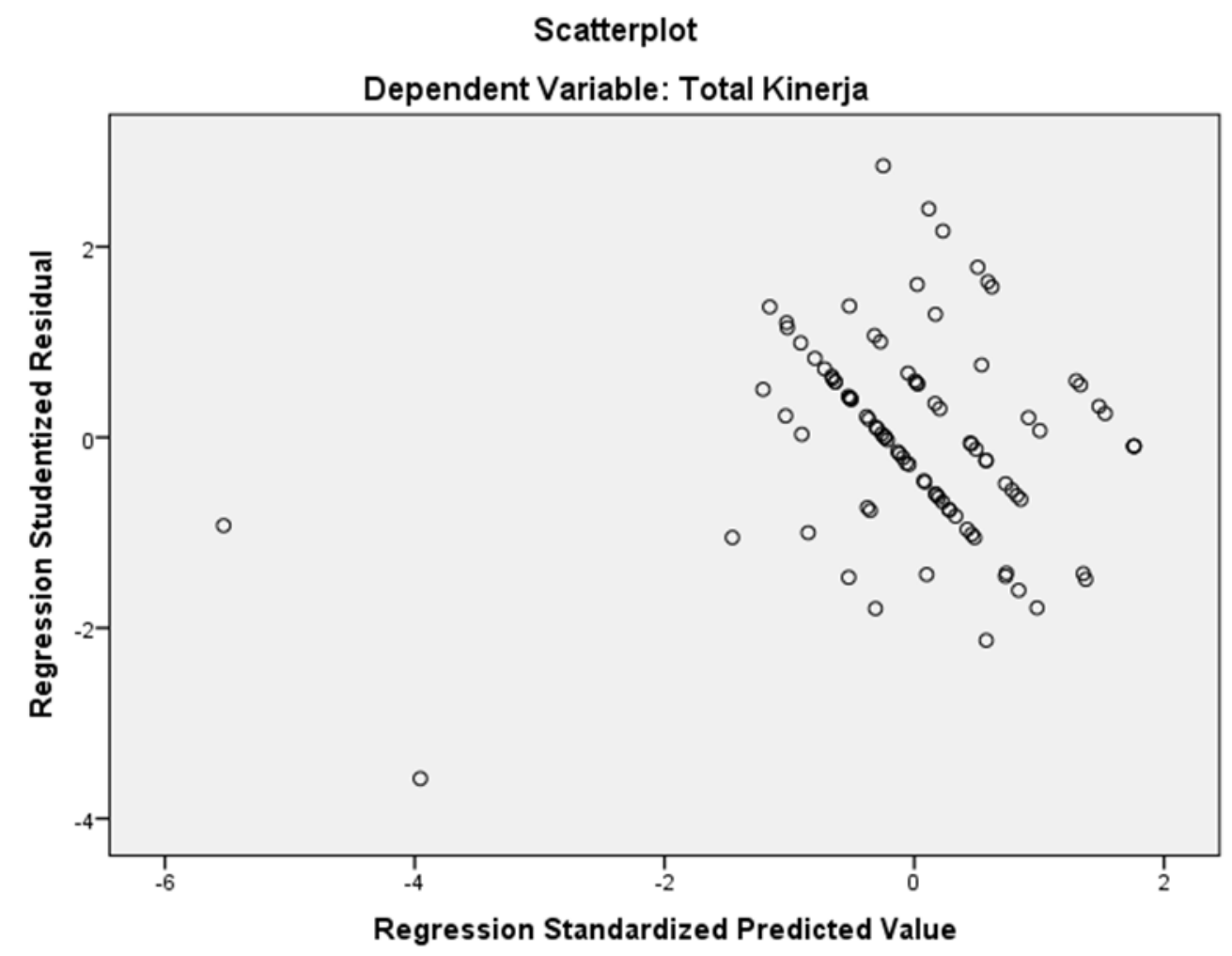

Gambar 2. Hasil Uji Heteroskedastisitas

Dari grafik scatterplot terlihat bahwa titiktitik menyebar secara acak, baik diatas maupun dibawah angka 0 pada sumbu $\mathrm{Y}$. Hal ini dapat disimpulkan bahwa tidak terjadi heteroskedastisitas pada model regresi, sehingga model regresi layak dipakai untuk memprediksi kinerja individu berdasarkan kesesuaian tugasteknologi, kepercayaan sistem informasi akuntansi, dan efektivitas sistem informasi akuntansi.

\section{Uji Autokorelasi}

Uji autokorelasi bertujuan menguji apakah dalam model regresi linear ada korelasi antara kesalahan pengganggu pada periode $\mathrm{t}$ dengan kesalahan pengganggu pada periode $\mathrm{t}-1$ (sebelumnya). Autokorelasi muncul karena observasi yang berurutan sepanjang waktu berkaitan satu sama lainnya (Ghozali, 2012: 110). Cara yang digunakan untuk mendeteksi ada atau tidaknya autokorelasi pada penelitian ini adalah dengan menggunakan Uji Durbin Watson (D-W test). Pengambilan keputusan ada tidaknya autokorelasi yaitu jika nilai $\mathrm{du}<\mathrm{d}<4-\mathrm{du}$. 
Tabel 7. Hasil Uji Autokorelasi

\begin{tabular}{|c|c|}
\hline \multicolumn{2}{|c|}{ Model Summary ${ }^{b}$} \\
\hline Model & Durbin-Watson \\
\hline 1 & 2,169 \\
\hline
\end{tabular}

Dapat dilihat nilai Durbin-Watson sebesar

2,169. Nilai ini akan dibandingkan dengan nilai tabel yang menggunakan nilai signifikan 5\%, jumlah sampel 96 dan jumlah variabel independen (k) adalah 3, maka dari tabel DW didapatkan nilai $\mathrm{du}=$ 1,733. Oleh karena itu, nilai DW 2,169 lebih besar dari batas atas (du) dan kurang dari 4 - du yaitu 2,267, maka dapat disimpulkan bahwa tidak terdapat autokorelasi positif atau negatif. Dengan kata lain tidak terdapat autokorelasi pada model regresi.

\section{Uji Hipotesis}

\section{Uji Koefisien Determinasi}

Koefisien determinasi digunakan untuk menguji goodness-fit dari model regresi, yang berarti mengukur seberapa jauh kemampuan model dalam menerangkan variasi variabel dependen. Dalam mengevaluasi model regresi sebaiknya digunakan nilai adjusted R2, karena setiap adanya penambahan variabel independen maka nilai adjusted R2 dapat meningkat maupun menurun sesuai dengan bagaimana pengaruh atas penambahan variabel tersebut (signifikan atau tidak).

Tabel 8. Hasil Uji Koefisien Determinasi

\begin{tabular}{|l|r|r|r|c|}
\hline Model & $R$ & $R$ Square & $\begin{array}{c}\text { Adjusted R } \\
\text { Square }\end{array}$ & $\begin{array}{c}\text { Std. Error of the } \\
\text { Estimate }\end{array}$ \\
\hline 1 &, $828^{\mathrm{a}}$ &, 685 &, 675 & 1,069 \\
\hline
\end{tabular}

a. Predictors: (Constant), Total Efektivitas, Total Kepercayaan, Total Kesesuaian

Dari hasil pengujian koefisien determinasi, didapat nilai adjusted $\mathrm{R}$ Square sebesar 0,675. Hal ini berarti $67,5 \%$ variabel kinerja individu dijelaskan oleh ketiga variabel indepeden, yaitu kesesuaian tugas-teknologi, kepercayaan sistem informasi akuntansi, dan efektivitas sistem informasi akuntansi. Sedangkan sisanya sebesar 32,5\% (100\% - 67,5\%) dijelaskan oleh variabel lain di luar model. 


\section{Uji ANOVA (F Test)}

Uji signifikansi simultan digunakan untuk mengetahui apakah semua variabel independen yang dimasukkan dalam model mempunyai pengaruh secara bersama-sama atau simultan terhadap variabel dependen (Ghozali, 2012). Uji statistik $\mathrm{F}$ ini memiliki taraf keyakinan
95\% dan standard error 5\%. Kriteria pengujian hipotesis dengan menggunakan uji statistik $\mathrm{F}$ adalah jika nilai signifikansi $\mathrm{F}(\mathrm{p}$-value $)<0,05$, maka hipotesis alternatif diterima, yang menyatakan bahwa semua variabel independen secara bersama-sama mempengaruhi variabel dependen (Ghozali, 2012).

Tabel 9. Hasil Uji ANOVA (F Test)

\begin{tabular}{|rl|r|r|r|r|r|}
\hline \multicolumn{1}{|l|}{ Model $^{2}$} & Sum of Squares & Df & Mean Square & F & Sig. \\
\hline \multirow{2}{*}{1} & Regression & 229,079 & 3 & 76,360 & 66,803 &, $000^{\mathrm{b}}$ \\
& Residual & 105,161 & 92 & 1,143 & & \\
& Total & 334,240 & 95 & & & \\
\hline
\end{tabular}

a. Dependent Variable: Total Kinerja

b. Predictors: (Constant), Total Efektivitas, Total Kepercayaan, Total Kesesuaian

Dari uji ANOVA atau F total, didapat nilai F hitung sebesar 66,803 dengan tingkat signifikansi 0,000 atau lebih kecil dari 0,05. Hasil penelitian ini menunjukkan bahwa model regresi dapat digunakan untuk memprediksi kinerja individu atau dapat dikatakan bahwa ketiga variabel independen, yaitu yaitu kesesuaian tugasteknologi, kepercayaan sistem informasi akuntansi, dan efektivitas sistem informasi akuntansi secara simultan berpengaruh signifikan terhadap kinerja individu. Berdasarkan hasil pengujian tersebut, maka Ha4 diterima.
Uji Signifikansi Parameter Individual (t Test)

Uji statistik $\mathrm{t}$ digunakan untuk mengetahui pengaruh masing-masing variabel independen terhadap variabel dependen (Ghozali, 2012). Uji statistik t ini memiliki nilai signifikansi $\square=5 \%$. Kriteria pengujian hipotesis dengan menggunakan uji statistik $\mathrm{t}$ adalah jika nilai signifikansi $\mathrm{t}$ (p-value) $<0,05$, maka hipotesis alternatif diterima, yang menyatakan bahwa suatu variabel independen secara individual mempengaruhi variabel dependen (Ghozali, 2012). 
Tabel 10. Hasil Uji t

\begin{tabular}{|c|c|c|c|c|c|c|}
\hline \multicolumn{7}{|c|}{ Coefficients $^{a}$} \\
\hline \multirow{2}{*}{\multicolumn{2}{|c|}{ Model }} & \multicolumn{2}{|c|}{$\begin{array}{c}\text { Unstandardized } \\
\text { Coefficients }\end{array}$} & \multirow{2}{*}{$\begin{array}{c}\text { Standardized } \\
\text { Coefficients } \\
\text { Beta }\end{array}$} & \multirow[t]{2}{*}{$t$} & \multirow[t]{2}{*}{ Sig. } \\
\hline & & $\mathrm{B}$ & Std. Error & & & \\
\hline \multirow{4}{*}{1} & (Constant) &,- 401 & ,946 & &,- 424 & ,673 \\
\hline & Total Kesesuaian & 215 & ,041 & ,429 & 5,271 & ,000 \\
\hline & Total Kepercayaan & ,434 & ,060 &, 534 & 7,277 & ,000 \\
\hline & Total Efektivitas &,- 018 & ,033 &,- 042 &,- 541 &, 590 \\
\hline
\end{tabular}

a. Dependent Variable: Total Kinerja

Tabel 10 menunjukkan bahwa variabel kesesuaian tugas-teknologi memiliki nilai $\mathrm{t}$ hitung sebesar 5,271 dengan tingkat signifikansi sebesar 0,000 atau lebih kecil dari 0,05. Hal ini berarti variabel kesesuaian tugas-teknologi memiliki pengaruh signifikan terhadap kinerja individu. Hasil penelitian ini sejalan dengan penelitian Akbar et al. (2010), Susilawati dan Sunarti (2011), dan Lindawati dan Salamah (2012) yang menyatakan bahwa kesesuaian tugasteknologi memiliki pengaruh signifikan terhadap kinerja individu. Namun, hasil penelitian ini bertentangan dengan penelitian yang dilakukan oleh Salamah (2012) dimana variabel kesesuaian tugas tidak memiliki pengaruh signifikan terhadap kinerja individu.

Variabel kepercayaan sistem informasi akuntansi memiliki nilai t hitung sebesar 7,277 dengan tingkat signifikansi 0,000 atau lebih kecil dari 0,05 . Hal ini berarti variabel kepercayaan sistem informasi akuntansi memiliki pengaruh signifikan terhadap kinerja individu. Hasil penelitian ini sejalan dengan penelitian Sari (2009) dan Jumaili (2005) yang menyatakan bahwa kepercayaan sistem informasi memiliki pengaruh signifikan terhadap kinerja individu.

Variabel efektivitas sistem informasi akuntansi memiliki nilai $\mathrm{t}$ hitung sebesar -0,541 dengan tingkat signifikansi 0,590 atau lebih besar dari 0,05. Hal ini berarti variabel efektivitas sistem informasi akuntansi tidak memiliki pengaruh signifikan terhadap kinerja individu. Dengan demikian, pengguna sistem informasi akuntansi di pasar swalayan tidak dapat mengukur seberapa jauh output atau informasi yang dihasilkan itu efektif terhadap kinerjanya. Hasil penelitian ini sejalan dengan penelitian Sajady et al. (2008) yang menyatakan bahwa sistem informasi akuntansi tidak memiliki 
pengaruh signifikan terhadap kinerja individu. Namun, hasil penelitian ini bertentangan dengan penelitian yang dilakukan oleh Sari (2009) dimana variabel efektivitas penggunaan teknologi

$$
\mathrm{Y}=-0,401+0,215 \mathrm{X} \_1+0,434 \mathrm{X} \_2-0,018 \mathrm{X} \_3+\mathrm{e}
$$

Keterangan:

$\begin{array}{lll}\mathrm{Y} & : & \text { Kinerja individu } \\ \mathrm{X}_{1} & : & \text { Kesesuaian tugas-teknologi } \\ \mathrm{X}_{2} & : & \text { Kepercayaan sistem informasi akuntansi } \\ \mathrm{X}_{3} & : & \text { Efektivitas sistem informasi akuntansi } \\ \mathrm{e} & : & \text { Error }\end{array}$

Dari persamaan regresi yang dihasilkan dapat disimpulkan bahwa konstanta sebesar $-0,401$ yang berarti jika variabel independen dianggap konstan, maka kinerja individu sebesar $-0,401$ yang berarti kinerja individu tersebut kurang baik. Koefisien regresi $X_{1}$ sebesar 0,215 menunjukkan bahwa variabel kesesuaian tugas-teknologi memiliki hubungan positif terhadap kinerja individu, sehingga Ha1 diterima. Hal ini berarti semakin sesuai tugas yang dikerjakan dengan kemampuan individual dan teknologi yang digunakan, maka kinerja individu tersebut akan semakin meningkat.

Koefisien regresi $\mathrm{X}_{2}$ sebesar 0,434 menunjukkan bahwa variabel kepercayaan sistem informasi akuntansi memiliki hubungan positif terhadap kinerja individu, sehingga $\mathrm{Ha} 2$ diterima. Hal ini berarti karyawan merasa bahwa sistem itu penting, sehingga yakin untuk menggunakannya. Semakin yakin karyawan pasar swalayan bahwa sistem informasi akuntansi yang digunakan dapat membantu mengoptimalkan kinerja, maka kinerjanya akan semakin meningkat.

Koefisien regresi $X_{3}$ sebesar $-0,018$ menunjukkan bahwa variabel efektivitas sistem informasi akuntansi memiliki hubungan negatif terhadap kinerja individu, sehingga Ha3 tidak dapat diterima. Hal ini berarti persepsi pembuat keputusan bahwa output informasi yang tersedia memenuhi kebutuhan mereka untuk koordinasi dan pengendalian organisasi tidak berpengaruh terhadap kinerjanya. Dengan kata lain, pengguna tidak menganggap bahwa output informasi yang dihasilkan tersebut dapat meningkatkan kinerjanya. Hal ini disebabkan oleh kompleksitas sistem SAP 
yang digunakan pada pasar swalayan, sedangkan sebagian besar karyawan yang menggunakan SAP tersebut hanya merupakan lulusan SMA.

\section{KESIMPULAN}

Kesimpulan

Kesesuaian tugas-teknologi memiliki hubungan positif terhadap kinerja individu, sehingga Hal diterima. Hal ini berarti semakin sesuai tugas yang dikerjakan dengan kemampuan individual dan teknologi yang digunakan, maka kinerja individu tersebut akan semakin meningkat. Variabel kesesuaian tugas-teknologi memiliki nilai $\mathrm{t}$ hitung sebesar 5,271 dengan tingkat signifikansi sebesar 0,000 atau lebih kecil dari 0,05 . Hal ini berarti variabel kesesuaian tugas-teknologi memiliki pengaruh signifikan terhadap kinerja individu. Hasil penelitian ini sejalan dengan penelitian Akbar et al. (2010), Susilawati dan Sunarti (2011), dan Lindawati dan Salamah (2012) yang menyatakan bahwa kesesuaian tugasteknologi memiliki pengaruh signifikan terhadap kinerja individu. Namun, hasil penelitian ini bertentangan dengan penelitian yang dilakukan oleh Salamah (2012) dimana variabel kesesuaian tugas tidak memiliki pengaruh signifikan terhadap kinerja individu.
Kepercayaan sistem informasi akuntansi memiliki hubungan positif terhadap kinerja individu, sehingga $\mathrm{Ha} 2$ diterima. Hal ini berarti semakin yakin karyawan pasar swalayan bahwa sistem informasi akuntansi yang digunakan dapat membantu mengoptimalkan kinerja, maka kinerjanya akan semakin meningkat. Variabel kepercayaan sistem informasi akuntansi memiliki nilai $\mathrm{t}$ hitung sebesar 7,277 dengan tingkat signifikansi 0,000 atau lebih kecil dari 0,05. Hal ini berarti variabel kepercayaan sistem informasi akuntansi memiliki pengaruh signifikan terhadap kinerja individu. Hasil penelitian ini sejalan dengan penelitian Sari (2009) dan Jumaili (2005) yang menyatakan bahwa kepercayaan sistem informasi memiliki pengaruh signifikan terhadap kinerja individu.

Efektivitas sistem informasi akuntansi memiliki hubungan negatif terhadap kinerja individu, sehingga $\mathrm{Ha} 3$ tidak dapat diterima. Hal ini berarti persepsi pembuat keputusan bahwa output informasi yang tersedia memenuhi kebutuhan mereka untuk koordinasi dan pengendalian organisasi tidak berpengaruh terhadap kinerjanya. Dengan kata lain, pengguna tidak menganggap bahwa output informasi yang dihasilkan tersebut dapat meningkatkan kinerjanya. Hal ini disebabkan oleh kompleksitas sistem SAP 
yang digunakan pada pasar swalayan, sedangkan sebagian besar karyawan yang menggunakan SAP tersebut hanya merupakan lulusan SMA. Variabel efektivitas sistem informasi akuntansi memiliki nilai $\mathrm{t}$ hitung sebesar $-0,541$ dengan tingkat signifikansi 0,590 atau lebih besar dari 0,05. Hal ini berarti variabel efektivitas sistem informasi akuntansi tidak memiliki pengaruh signifikan terhadap kinerja individu. Hasil penelitian ini sejalan dengan penelitian Sajady et al. (2008) yang menyatakan bahwa sistem informasi akuntansi tidak memiliki pengaruh signifikan terhadap kinerja individu. Namun, hasil penelitian ini bertentangan dengan penelitian yang dilakukan oleh Sari (2009) dimana variabel efektivitas penggunaan teknologi sistem informasi memiliki pengaruh signifikan terhadap kinerja individu.

Kesesuaian tugas-teknologi, kepercayaan sistem informasi akuntansi, dan efektivitas sistem informasi akuntansi secara simultan berpengaruh signifikan terhadap kinerja individu. Hal ini dibuktikan dengan nilai statistik $\mathrm{F}$ sebesar 66,803 dengan tingkat signifikansi 0,000 atau lebih kecil dari 0,05, sehingga Ha4 diterima.

Keterbatasan

1. Jumlah responden yang digunakan hanya 96 responden sehingga penelitian tidak dapat mengeneralisasi pengguna sistem informasi akuntansi pada pasar swalayan yang berada di kota Tangerang.

2. Objek penelitian ini hanya berfokus pada pasar swalayan yang berada di kota Tangerang.

3. Nilai adjusted R Square sebesar 0,675 yang berarti $67,5 \%$ variabel kinerja individu dijelaskan oleh ketiga variabel indepeden, yaitu kesesuaian tugas-teknologi, kepercayaan sistem informasi akuntansi, dan efektivitas sistem informasi akuntansi. Sedangkan sisanya sebesar $32,5 \%$ dijelaskan oleh variabel lain yang tidak ada dalam penelitian ini.

4. Penelitian ini terbatas hanya meneliti tiga variabel, yaitu kesesuaian tugas-teknologi, kepercayaan sistem informasi akuntansi, dan efektivitas sistem informasi akuntansi, yang mempengaruhi kinerja individu.

Saran

Peneliti selanjutnya dapat meneliti dengan jumlah responden yang lebih banyak dengan menyebarkan kuesioner dalam jumlah yang lebih banyak. 
Peneliti selanjutnya dapat memperluas objek penelitian menjadi tidak hanya pasar swalayan, tetapi juga perusahaan retail secara umum agar hasil penelitian dapat lebih optimal.

Peneliti selanjutnya dapat menambahkan variabel yang terdapat dalam penelitian ini karena masih ada faktor-faktor lain yang dapat dijadikan bahan penelitian dalam mempengaruhi kinerja individu, seperti pengetahuan teknologi informasi, pemanfaatan teknologi informasi, dan lainnya.

Saran yang diberikan untuk praktisi adalah:

Manajemen pasar swalayan dapat meningkatkan kinerja karyawannya dengan memperhatikan kesesuaian antara tugas, teknologi yang digunakan, dan kemampuan individu tersebut.

Pengguna sistem informasi akuntansi pada pasar swalayan perlu yakin bahwa sistem informasi akuntansi yang digunakan perusahaan dapat meningkatkan kinerja, dan mau belajar untuk menggunakan sistem informasi baru agar kinerjanya dapat semakin optimal.

\section{DAFTAR PUSTAKA}

Akbar, Nasrizal, Ratnawati, Vince, dan Novita, Vina. 2010. "Pengaruh Pengetahuan Teknologi Informasi, Pemanfaatan Teknologi Informasi, dan Faktor Kesesuaian TugasTeknologi Terhadap Kinerja Akuntan Internal". Dalam Jurnal Ekonomi. Vol. 18, No. 2, Juni 2010, hal. 79-91.

Dehghanzade, Hamed, Moradi, Mahammad Ali, dan Raghibi, Mahvash. 2011. "A Survey of Human Factors' Impacts on the Effectiveness of Accounting Information System". Dalam International Journal of Business Administration. Vol. 2, No. 4, November 2011.

El-Dalabeeh, Abd el-Rahman kh. dan Alshbiel, Seif Obeid. 2012. "The Role of Computerized Accounting Information Systems in Reducing the Cost of Medical Services at King Abdullah University Hospital". Dalam Interdisciplinary Journal of Contemporary Research in Business. Vol. 4, No. 6, Oktober 2012.

Ghozali, Imam. 2012. Aplikasi Analisis Multivariate dengan Program IBM SPSS 20. Semarang: Badan Penerbit Universitas Diponegoro.

Goodhue, Dale L., dan Thompson, Ronald L.. 1995. "Task-Technology Fit and Individual Performance". Dalam MIS Quarterly, Vol. 19. No. 2, Juni 1995, hal. 213-236.

Hall, James A. 2008. Accounting Information Systems. United States: South-Western Cengage Learning. 
-- . 2011. Information Technology Auditing and Assurance. United States of America: SouthWestern Cengage Learning.

Hamzah, Ardi. 2009. "Evaluasi Kesesuaian Model Keperilakuan dalam Penggunaan Teknologi Sistem Informasi di Indonesia". Dalam Seminar Nasional Aplikasi Teknologi Informasi 2009. Yogyakarta, 20 Juni 2009.

Heizer, Jay dan Render, Barry. 2010. Manajemen Operasi. Edisi 9 No.2. Jakarta: Salemba Empat.

Jumaili, Salman. 2005. "Kepercayaan Terhadap Teknologi Sistem Informasi Baru dalam Evaluasi Kinerja Individual”. Dalam Kumpulan Materi Simposium Nasional Akuntansi VIII. Solo, 1516 September 2005.

Kinicki, Angelo dan Williams, Brian K.. 2009. Management: A Practical Introduction. New York: McGrawHill.

Lindawati, dan Salamah, Irma. 2012. "Pemanfaatan Sistem Informasi dan Teknologi Informasi Pengaruhnya Terhadap Kinerja Individual Karyawan". Dalam Jurnal Akuntansi dan Keuangan, Vol. 14, No. 1, Mei 2012, hal. 56-68.

O'Brien, James A dan Marakas, George M.. 2008. Management Information Systems. New York: McGraw-Hill.

Pennington, Robin, Wilcox, H.Dixon, dan Grover, Varun. 2003. "The Role of System Trust in Business-toConsumer Transactions". Dalam Journal of Management Information System Vol. 20, No. 3, hal. 197-226.
Petter, Stacie, DeLone, William, dan McLean, Ephraim. 2008. "Measuring Information System Success: Models, Dimensions, Measures, and Interrelationships". Dalam European Journal of Information Systems No. 17, Mei 2008, hal. 236-263.

Romney, Marshal B. dan Steinbart, Paul J.. 2012. Accounting Information Systems. United States: Pearson.

Sajady, H., M. Dastgir, dan Nejad, H.Hashem. 2008. "Evaluation of The Effectiveness of Accounting Information System". Dalam International Journal of Information Science \& Technology Vol. 6, No. 2, Juli 2008.

Salamah, Irma. 2012. "Utilization of IT and the Effects on Individual Performance of Lecturers at State Polytechnic Sriwijaya". Dalam Journal of Economics, Business, and Accountancy Ventura Vol. 15, No. 1, April 2012, hal. 31-46.

Sari, Maria M. Ratna. 2009. "Pengaruh Efektivitas Penggunaan dan Kepercayaan terhadap Teknologi Sistem Informasi Akuntansi terhadap Kinerja Individual pada Pasar Swalayan di Kota Denpasar". Dalam Ekonomi Audi : Audi Jurnal Akuntansi dan Bisnis Vol. 4, No. 1, Januari 2009.

Seddon, Peter B. dan Kiew, Min-Yen. 2007. "A Partial Test and Development of DeLone and McLean's Model of IS Success". Dalam Australasian Journal of Information Systems Vol. 4, No. 1.

Sekaran, Uma dan Bougie, Roger. 2010. Research Methods for Business. Great Britain: Wiley. 
Sugiyono. 2010. Statistika untuk Penelitian. Bandung: Alfabeta.

Suliyanto. 2011. Ekonometrika Terapan: Teori \& Aplikasi dengan SPSS. Yogyakarta: Andi.

Susilawati, Clara dan Sunarti, Sri. 2011. "Faktor-Faktor yang Mempengaruhi Pemanfaatan Teknologi Informasi oleh Akuntan". Dalam Jurnal Dinamika Akuntansi Vol. 3 No. 2, September 2011.
Tennakoon, Hemamali dan Syed, Rehan. 2011. "Impact of the use of Information Technology on Employee stress level and Job satisfaction in the banking and financial sector of Sri Lanka". Dalam International Conference on Business Management. Vol. 5, Desember 2011, hal. 41-54.

Vaassen, Eddy, Meuwissen, Roger dan Schelleman, Caren. 2009. Accounting Information Systems and Internal Control. Edisi 2. United Kingdom: Wiley.

Widarno, Bambang. 2008. "Efektivitas Perencanaan dan Pengembangan Sistem Informasi". Dalam Jurnal Akuntansi dan Sistem Teknologi Informasi Vol. 6, No. 1, April 2008, hal. 1-13. 